\title{
Characterisation, evolutionary trends and mapping of putative resistance and defence genes in Actinidia (kiwifruit)
}

\author{
Lena G. Fraser • Paul M. Datson • Gianna K. Tsang • \\ Kelvina I. Manako • Erik H. Rikkerink • \\ Mark A. McNeilage
}

Received: 24 September 2014 / Revised: 18 January 2015 / Accepted: 27 January 2015 /Published online: 8 February 2015

(C) The Author(s) 2015. This article is published with open access at Springerlink.com

\begin{abstract}
A virulent strain of Pseudomonas syringae actinidae has invaded kiwifruit (genus Actinidia) orchards in New Zealand, making the study of Actinidia resistance genes critical. Examination of expressed sequence tag (EST) libraries constructed in various species of Actinidia showed that, based on homologies to Arabidopsis, many families of resistance genes were represented. The mapping of these genes to establish their chromosomal positions on the Actinidia chinensis genetic linkage map was facilitated by designing 71 primer pairs to the EST sequences. The genetic markers mapped across 22 of the linkage groups, both as individuals and as members of a cluster. The clusters were generally homologous in nature, though heterologous examples were present. A sample of genes representing both the basal defence
\end{abstract}

Communicated by R. Burdon

Electronic supplementary material The online version of this article (doi:10.1007/s11295-015-0846-1) contains supplementary material, which is available to authorized users.

L. G. Fraser $(\bowtie) \cdot$ P. M. Datson • G. K. Tsang • K. I. Manako •

E. H. Rikkerink $\cdot$ M. A. McNeilage

The New Zealand Institute for Plant \& Food Research Limited, Private Bag 92-169, Auckland Mail Centre, Auckland 1142, New Zealand

e-mail: lena.fraser@plantandfood.co.nz

P. M. Datson

e-mail: paul.datson@plantandfood.co.nz

G. K. Tsang

e-mail: giannasdh@gmail.com

K. I. Manako

e-mail: kelvina.manako@plantandfood.co.nz

E. H. Rikkerink

e-mail: erik.rikkerink@plantandfood.co.nz

M. A. McNeilage

e-mail: mark.mcneilage@plantandfood.co.nz and the resistance-gene mediated defence pathways, here termed collectively 'resistance genes', was characterised. Chromosomal sites of resistance gene markers representing a range of such genes have been identified and can be considered during the selection of parents in breeding programmes.

Keywords Kiwifruit - Actinidia - Resistance genes · Defence genes - Evolution - Mapping

\section{Introduction}

Plants are under constant attack by various potentially pathogenic microbes. To counter this offensive, plants have developed detection and response systems that identify pathogen signals and initiate appropriate defences. Unlike animals which have mobile defensive systems, and both adaptive and innate immune systems, plants rely on the innate immunity of each cell and on systemic signals originating from infection sites which initiate defensive cascades. Early studies among accessions of the model plant Arabidopsis found that the plants showed variation in disease resistance and susceptibility when inoculated with different strains of the bacterial pathogen Pseudomonas syringae (Dong et al. 1991; Whalen et al. 1991; Dangl et al. 1992). Some of this variation was the result of recognition of products of the specific bacterial avirulence genes avrRpt 2 and avrRpml, which allowed the plant to restrict the growth of an otherwise virulent $P$. syringae strain. This reaction identified $a v r-R$ gene pairs in Arabidopsis, and elucidation of the gene-for-gene hypothesis, first developed by Flor (1956) on studies of host-pathogen interaction of flax with Melampsora lini (rust), followed (Frank 1996a, b; Parker 1996; Baker et al. 1997; Agrawal and Lively 2002). The resistance gene response to an $a v r$ effector 
is credited with initiating a series of signalling cascades such as rapid oxidative bursts, deposition of cell wall components for strengthening, the induction of defence genes and rapid cell death at the site of infection, all leading to disease resistance (Morel and Dangl 1997).

Several disease-resistance genes, $R$ genes, have been positionally cloned, the first being Pto, isolated from tomato (Martin et al. 1993). Pto was found to encode a cytoplasmic, membrane-bound, serine-threonine kinase. Cloning of the Arabidopsis $R$ genes RPS 2 and RPM1, and the tobacco $N$ and flax $L$ genes followed (Bent et al. 1994; Mindrinos et al. 1994; Whitham et al. 1994; Ellis et al. 1995). By the late 1990s, it was recognised that the resistance to all classes of microbial plant pathogens and insects could be conferred by a related gene set of NB-LRR proteins, so called for their characteristic nucleotide-binding (NB) and leucine-rich repeat (LRR) domains that act as molecular receptors. NB-LRR proteins have since been found to be ubiquitous in seed-bearing plants (Kedzierske et al. 2004; Torii 2004).

Analysis of NB-LRR genes established that the NB domain was involved in signalling and contained several highly conserved and strictly ordered motifs such as the phosphate-binding loop (P-loop), Kinase 2 and Gly-LeuPro-Leu (GLPL) motifs (Meyers et al. 1999; Pan et al. 2000; Belkhadir et al. 2004). The LRR domain was suggested to be central to pathogen recognition specificity, as the motif was typically involved in protein-protein interactions and ligand binding with pathogen-derived molecules (Ellis et al. 1999; Tan and Wu 2012). The NB-LRR genes may be divided into two classes, distinguished by the presence or absence of the N-terminal Toll/interleukin-1 receptor (TIR) homology region (Meyers et al. 1999; Richly et al. 2002). Most of the genes that lack the TIR region have a coiled-coil (CC) motif. Dicotyledonous plants have been shown to have both TIR-NB-LRR and CC-NB-LRR resistance genes in relative abundance, but monocot proteins generally lack the TIR region.

Many of the proteins that have been identified point to the importance of secretion in defence, which was predictable based on the extracellular nature of most plant pathogens. Bacterial virulence factors, also known as effector proteins, injected and acting inside host cells, are recognised by the NB-LRR proteins, which leads to effector-triggered immunity (ETI). The effectors deployed by the pathogen to specific sites of action within the host cell contribute to the pathogen's virulence, presumably by damping, delaying and impeding host cell responses (Nomura et al. 2011; Spoel and Dong 2012). Plants also recognise the presence of conserved pathogen molecules, collectively termed pathogen- or microbial-associated molecular patterns (PAMPs/MAMPs). Recognition of these elicitors is mediated by high-affinity cell surface receptors (Gómez-Gómez and Boller 2000; Shi et al. 2013).
Plant hormone signalling also plays a major role in determining the outcome of plant-pathogen interactions, with salicylic acid (SA), jasmonic acid (JA) and ethylene being among the best-characterised defence hormones (Shi et al. 2013).

Genes required for the function of the $R$ genes have also been identified. Non-race-specific disease resistance 1 (NDR1), encoding a plasma membrane-localised protein, was shown to be required for $R$ genes recognising both bacteria and oomycetes, thus indicating a conserved signalling mechanism exists for at least some $R$ genes (Century et al. 1997).

The genus Actinidia (kiwifruit) has long been of interest to New Zealand as the country that selected and commercialised the green-fleshed cultivar 'Hayward', Actinidia deliciosa (A. Chev.) C.F. Liang et A.R. Ferguson var. deliciosa, and the gold-fleshed 'Hort16A' Actinidia chinensis Planch. var. chinensis. While kiwifruit represent only a small proportion of the world-wide fresh fruit market, it is the leading export horticultural crop of New Zealand, and large breeding programmes support a well-established and expanding industry. In 2010 a virulent strain of Pseudomonas syringae pv. actinidiae (Psa) was identified as the causal agent for a recent economically damaging disease outbreak in Actinidia species in New Zealand.

New Zealand breeding germplasm had not previously been assessed for virulent Psa disease resistance so little was known about the resistance genes, or their genomic location. A gene-rich genetic map had identified all 29 linkage groups in the diploid species $A$. chinensis (Fraser et al. 2009), and an extensive Expressed Sequence Tag (EST) database had been compiled from many tissues and stages of development of the parent genotypes in the Actinidia breeding programmes (Crowhurst et al. 2008). Characterisation of the EST database had shown, through homologies to Arabidopsis and other sequenced genera, that putative resistance genes were represented. At the time of cDNA library construction Actinidia had not been challenged by the virulent strain of Psa, so none could be regarded as specific to the pathogen. Studies of strains of Psa causing disease in kiwifruit orchards in Italy had shown that none of the strains isolated possessed genes encoding the toxins phaseolotoxin or coronatine, known in other Psa strains, but all had effector proteins of the hop class (Ferrante and Scortichini 2010).

As an initial step to locate defence-related genes that may be important in the control, or alleviation, of the pathogeninduced symptoms of infection in Actinidia, we have characterised and added a selection of such genes to the genomic map of $A$. chinensis. This information will ensure that regions of the genome that harbour potential defence genes are marked, and considered, during the development of an extensive breeding programme aimed at supplying new cultivars to the industry. 


\section{Materials and methods}

\section{Plant material and DNA extraction}

An intraspecific mapping population of 272 plants was created in the diploid species $A$. chinensis. The parents were chosen for their geographic separation in China, and for the diversity of fruiting characteristics they exhibited, those of the male being inferred from the attributes of female siblings. The female parent originated from seed from Henan province, and the male parent from a seed accession from Guangxi province. Equal numbers of female and male plants were propagated after testing with the sex marker SmY (Gill et al. 1998). Genomic DNA was extracted from young leaves of both parental genotypes and every individual in the mapping population. A sample was ground to powder in liquid nitrogen before being processed through a DNeasy Plant Mini Kit (Qiagen ${ }^{\text {TM}}$ ) according to the manufacturer's instructions. The final eluate was $200 \mu \mathrm{l}$ in volume. $5 \mu \mathrm{l}$ of a 1:10 dilution of this eluate was used in each PCR reaction.

Putative defence-related gene identification

Candidate genes, likely to be associated with immune responses, were identified in the Plant \& Food Research Actinidia EST database according to homologies to known resistance genes studied in Arabidopsis. This information was used to select a list of ESTs, representing a variety of such genes, for genetic mapping. Gene families having sequence homology to resistance and defence genes conferring activity against Pseudomonas species were chosen for mapping. The sequence data are available in GenBank Data Libraries under accession nos. FG527909-FG403522. The Actinidia ESTs were selected based on length and suitability of sequence for primer design. The EST sequences were characterised using ClustalW and Geneious version 5.6.3 created by Biomatters, available from http://www.geneious.com. Conserved motifs indicative of gene activity were identified by the National Centre for Biotechnology Information Domains and Structures, Conserved Domain Search Service http://www. ncbi.nim.gov, Motif Search (GenomeNet, Japan) and Pfam The Pfam protein families database.

Microsatellite identification and primer design

Microsatellites from the EST libraries were identified in silico as described by Fraser et al. (2009). Primer pairs were designed for non-duplicated sequences using the software programme Primer3 (C1996, 1997, and 1998) and by examination of the sequence. Primer pair sequences were chosen that gave a theoretical PCR product size between 200 and $450 \mathrm{bp}$, with an annealing temperature of $58^{\circ} \mathrm{C}$, and with a $\mathrm{GC}$ content of approximately $50 \%$. Where possible, one of the primers of each pair was located before the microsatellite in the transcribed region, and the other was designed within the translated portion of the EST to facilitate marker transfer to other species. The primer pairs were synthesised and fluorescently labelled (Dye Sets DS-31 or DS-34) by Applied Biosystems, Australia. When a microsatellite was not found in the EST sequence, insertions and deletions (indels) were used as markers.

Polymerase chain reaction, electrophoresis, data analysis and map construction

Primer pairs were screened for PCR amplification and length polymorphism with DNA samples of both parents of the mapping population and 94 progeny (96-well plate trial). A reaction mix of $15 \mu \mathrm{l}$ containing $1 \times$ PCR buffer $(20 \mathrm{mM}$ Tris$\mathrm{HCl}, 50 \mathrm{mM} \mathrm{KCl}$ ), $\mathrm{MgCl}_{2} 5 \mathrm{mM}$ (the buffer and $\mathrm{MgCl}_{2}$ were those supplied with the polymerase), $0.2 \mathrm{mM}$ of each dNTPs, 4.5 pmol of each primer and 1.25 units of Platinum Taq polymerase (Invitrogen) was prepared for each DNA sample. About $12.5 \mathrm{ng}$ of genomic DNA was added in $5 \mu \mathrm{l}$ to bring the total PCR volume to $20 \mu \mathrm{l}$. PCRs were performed in a Techne ${ }^{\text {TM }}$ TC-412 thermal cycler with a single cycle of $94^{\circ}$ for 3 min preceding 35 cycles of denaturing at $94^{\circ}$ for $30 \mathrm{~s}$, annealing at $58^{\circ} \mathrm{C}$ for $30 \mathrm{~s}$ and elongation at $72^{\circ}$ for $1 \mathrm{~min}$. Single locus PCR reactions were carried out prior to combining to produce a three colour multiplex of products labelled with 6FAM, VIC or NED for analysis. The allelic content of each genotype was determined by capillary array electrophoresis in an ABI Prism ${ }^{\circledR} 3130$ Genetic Analyzer (Filter Set D, ROX $^{\mathrm{TM}}$ size standard) and analysed with GeneMapper ${ }^{\mathrm{TM}}$ Software Version 3.7 (Applied Biosystems). All markers were independently scored by two people for verification. Chisquared tests of goodness-of-fit to expected segregation ratios of $1: 1: 1: 1,1: 2: 1,3: 1$ or $1: 1$ were carried out for all markers segregating in the $\mathrm{F}_{1}$ progeny. Female, male and consensus linkage maps were constructed for the $F_{1}$ progeny using JoinMap $^{\circledR} 3.0$.

\section{Results}

We identified a set of 71 putative defence-resistance genes from an extensive Actinidia EST database through comparison with the characterised Arabidopsis database. They represented various resistance gene families that have been mapped to identify their positions on linkage groups (Online Resource Table 1).

A set of 71 primer pairs (Online Resource Table 2), designed to amplify those genes and to place the gene markers on the genetic map of $A$. chinensis, amplified a total of 97 polymorphic loci that were mapped. The number of loci mapped possibly indicates the presence of gene families. 
Table 1 The distribution of loci identified on the A. chinensis genetic linkage map with primers designed to a variety of resistance gene families

Lingkage group

\begin{tabular}{|c|c|c|c|c|c|c|c|c|c|c|c|c|c|c|c|c|c|c|c|c|c|}
\hline 1 & 2 & 3 & 4 & 5 & 7 & 10 & 11 & 13 & 14 & 15 & 17 & 18 & 19 & 20 & 21 & 22 & 23 & 24 & 25 & 27 & 29 \\
\hline \multicolumn{22}{|c|}{ Number of loci } \\
\hline 11 & 3 & 1 & 2 & 9 & 2 & 6 & 3 & 2 & 4 & 5 & 1 & 3 & 1 & 6 & 6 & 10 & 3 & 8 & 7 & 1 & 3 \\
\hline
\end{tabular}

Linkage groups $1,5,22,24$, and 25 carried the most loci, from 11 to 7 , and the loci were present both in clusters and as individual markers

The marker loci mapped to 22 of the 29 linkage groups identified by Joinmap (Table 1), the number of loci on each linkage group varying between 1 and 11 . Of the 97 polymorphic loci mapped, 37 were fully informative, 24 were female informative, 28 were male informative and 8 were partly informative.

The linkage groups most heavily populated with putative resistance gene markers were LG 1(11), LG 5(9), LG 22(10), LG 24(8) and LG 25(7) (Fig. 1). This result may reflect the fact that only a small number of putative resistance gene markers were tested, and/or that some of the linkage groups of the genetic map do not carry as many markers. Resistance genes have been found to form clusters that can be composed of genes of the same gene family (homologous clusters) or of mixed families (heterologous clusters; Michelmore and
Meyers 1998; Kuang et al. 2004). Similarly, we detected homologous and heterologous clusters. Some markers were clustered, while some were isolated among existing markers.

The nucleotide binding (NB)-leucine-rich repeat (LRR) resistance gene family

The nuclear binding site (NBS; NBS-ARC) of the sample sequences was identified with the Motif Searching tool. When the sequences were aligned using CLUSTALW multiple alignment programme, together with representative Arabidopsis data At3g070401.1, both conserved and variable amino acid sequences were observed (Fig. 2).

As the NBS domain is central to functional competence, specific motifs must be present in the genes to ensure activity.
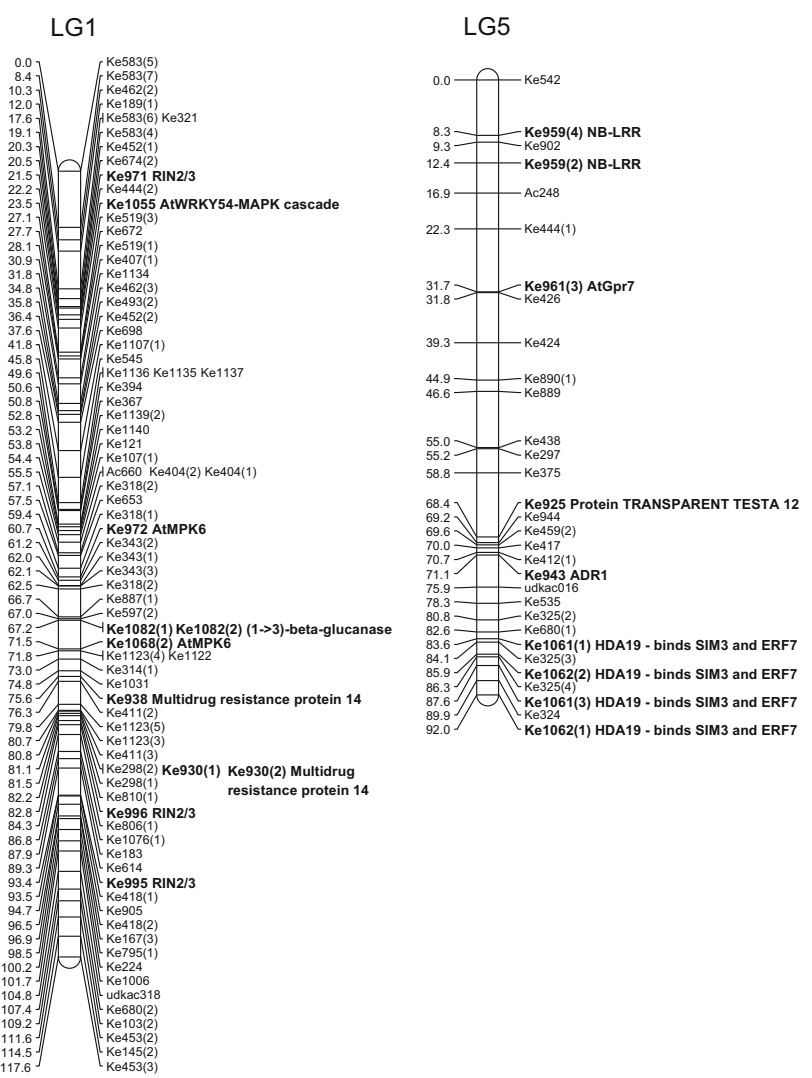

Fig. 1 Linkage groups with the highest numbers of resistance gene markers. With reference to the $A$. chinensis genetic linkage map, they were numbered LG 1 with eleven markers, LG 5 with nine markers,

\section{LG22}

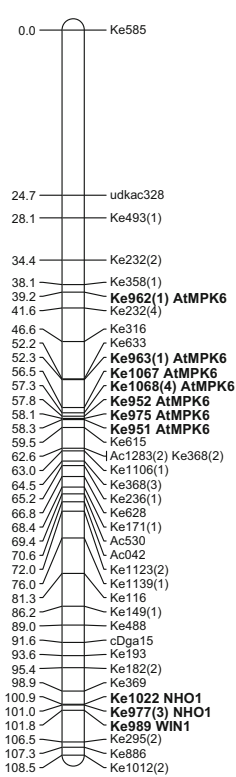

LG24

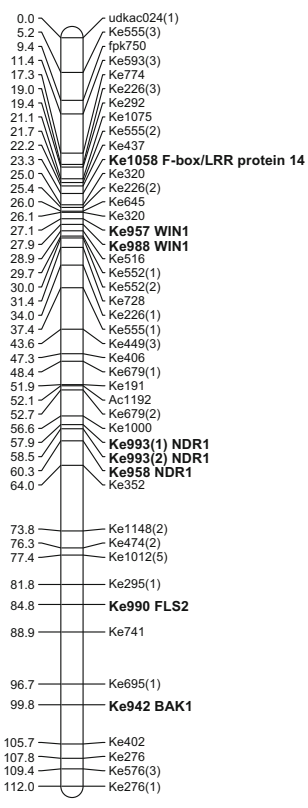

LG25

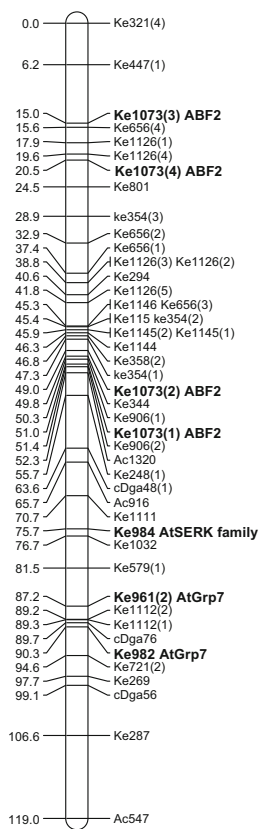

LG 22 with ten markers, LG 24 with eight markers and LG 25 with seven markers. The putative genes that the markers represent belong to many resistance gene families 


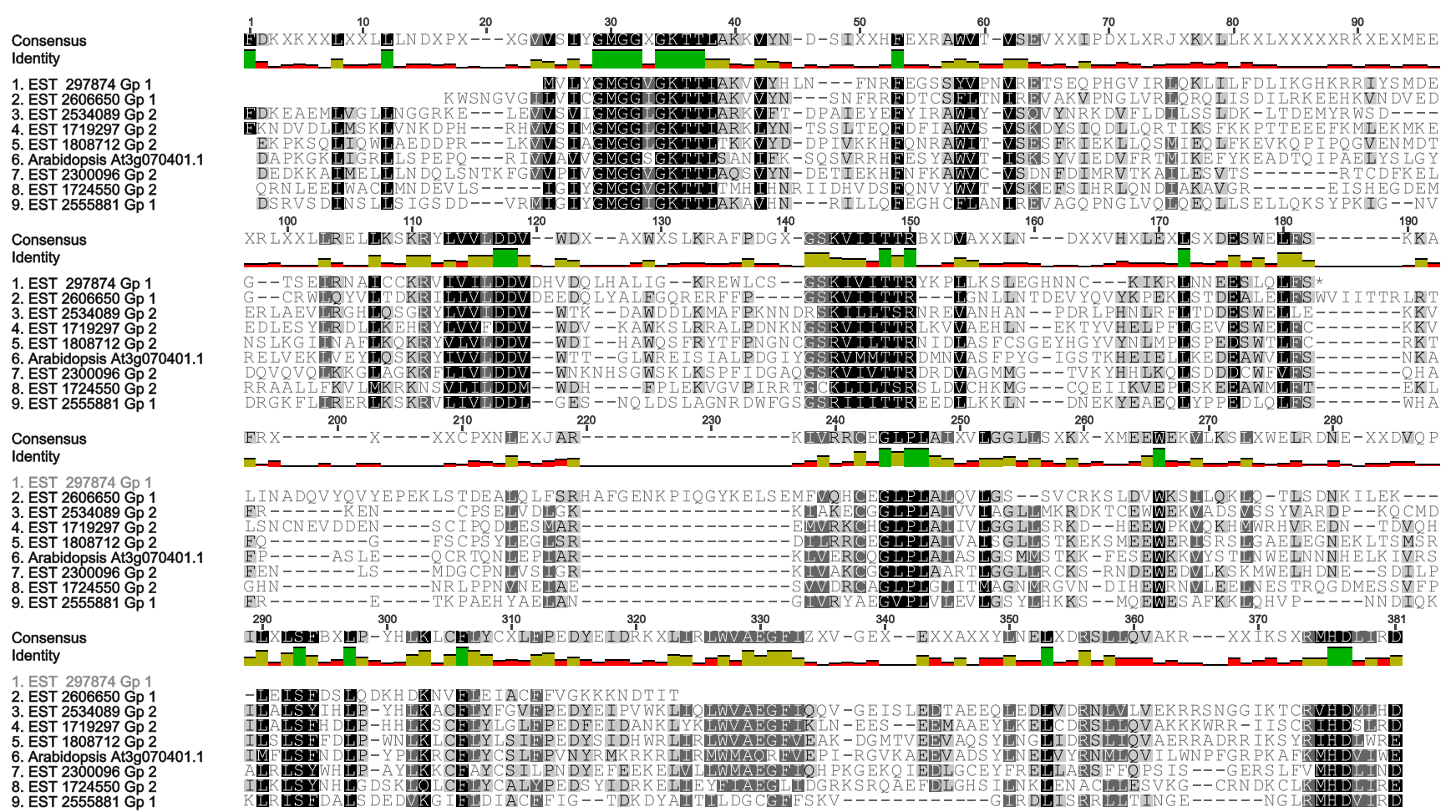

Fig. 2 The NBS-ARC domain of the sample set of Actinidia genes and reference Arabidopsis data were found to have strongly conserved sites relating to function. The P-loop and kinase motifs are shaded in black, as are the strongly hydrophobic site GLPL and the final conserved site within the NBS domain MHDL. Other conserved sites are indicated in grey shading
Three peptide motifs, kinase 1a or the P-loop, kinase 2 and kinase $3 \mathrm{a}$, that are critical for nucleotide binding in various ATP/GTP binding proteins were highly conserved in the domain. All three function in the interaction with the nucleotide. The phosphate-binding P-loop, with the pattern G-x(4)-G$\mathrm{K}-[\mathrm{TS}]$, forms a glycine-rich, flexible loop between a $\beta$ strand and an $\alpha$-helix, the loop then interacting with one of the phosphate groups of the nucleotide. The kinase 2 motif was seen to have an invariant aspartic acid residue that coordinates the divalent metal ion that is required for phosphotransfer reactions, while the third motif is that of kinase $3 \mathrm{a}$, involved in binding the purine base or pentose of the nucleotide (Tameling et al. 2002). The GLPL motif or 'hydrophobic domain' was conserved in the sample set as was the MHDL motif at the C-terminal of the domain. Some less highly conserved motifs were seen, and the domain was variable in length among the individual sequences.

Truncated messages were also detected. Derived amino acid sequences were found where premature stop codons terminated the message before all the conserved motifs were read. The sequence of EST 297874 in the alignment was found to have a stop codon after the kinase motifs and before the GLPL motif, and EST 2606650 was terminated toward the end of the NBS domain. Their presence in the EST database indicates that the genes were transcribed, however, we have no evidence that functional products were made.
There are residues within the domain that are specific to groups of NB-LRR genes and permit them to be divided into two classes (Fig. 3). In group 1, a conserved phenylalanine (F) is followed, five residues downstream, by a second phenylalanine. In group 2, the second phenylalanine is replaced by a tryptophan (W) residue. Downstream of the second conserved site where four hydrophobic residues are followed by two negatively charged aspartic acid residues, a highly conserved tryptophan is seen only in group 2 genes. The F-F configuration is diagnostic for the TIRNBS-LRR group 1, while the F-W identifies the CC-NBSLRR group 2. Consistent with the situation that has been described in eukaryotes, examples of both groups were seen in the Actinidia sample set.

Leucine residues were highly represented in the sequences of the NBS sample set, being $12 \%$ of the total residues, as were isoleucine and valine, at 6.5 and $7.1 \%$ respectively. Overall, the hydrophobic amino acids accounted for $52.4 \%$ of the residues comprising the region. These residues would be expected to be located in the core of the protein and shielded from the aqueous environment by the rest of the protein. The sample set were found to have relatively low percentages of identity (Table 2) both between group 1 and group 2 examples, and also within each group, suggesting that the genes represented have long been individual entities. The sequence variation also indicates that the protein region is not 


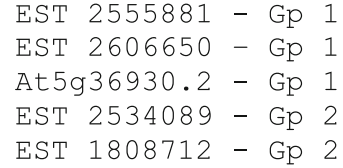

Fig. 3 Two classes of NB-LRR genes can be distinguished by their conserved amino acid sequence. In group 1, the TIR-NBS-LRR group, a conserved phenylalanine (F) residue at position 24 is followed by a second highly conserved $\mathrm{F}$ five residues downstream. In group 2, the

\section{KIGNVDRGK-FLIRERLKSKRVLIVLDDLGES- KVNDVEDG-CRWLQYVLTDKRILLVLDDVDEED EFKGLDHA----VKERERSKRVLLVVDDVDDV- DE-----RLAEVLRGHLQSGRYLVVIDDVWTKD VENMDTNSLKGI INAFLKQKRYVLVLDDVWDIH \\ $2 \uparrow$}

CC-NBS-LRR group, the second residue is replaced by a highly conserved tryptophan (W). Downstream, where four hydrophobic residues are followed by two negatively charged aspartic acid residues, a highly conserved $\mathrm{W}$ is seen only in group 2 genes important in gene function/activity, and can tolerate variation in amino acid sequence. While the motif features of At3g070401.1 indicate that it should belong to group 1, it can be seen to have higher sequence percentage identity with members of Group 2.

In a distance tree, constructed by Neighbor-Joining in Geneious, the three group 1 TIR-NBS-LRR genes were clustered together. The non TIR-NBS-LRR genes formed two separate clades, one of which was more closely associated with the TIR-NBS-LRR clade than with the other CC-NBSLRR clade (Fig. 4).

\section{The LRR domain}

Using the MHDV conserved motif in the NBS domain as reference point, and continuing to the $\mathrm{C}$ terminal, the length of the LRR domain among the sample set was quite variable ranging in length from 381 amino acid residues in EST 1719294 to 837 amino acid residues in EST 2300096
(Fig. 5). While the domains showed similarities in the conserved motifs of the LRRs, the sample set had varying numbers of motifs, in general reflecting the length of the domain.

We examined the leucine-rich repeat motif with the highly conserved pattern LxxLxLxx[N/C]xL where ' $\mathrm{L}$ ' can be leucine (L), isoleucine (I) or valine (V) and the 'N/C' (asparagine/cysteine) can also be represented by alanine, threonine or serine. It has been suggested that this conserved, or classic, motif can be modified to a shortened motif of LxxLxL as molecular modelling suggests this motif is sufficient to create the characteristic horseshoe curvature to proteins with 20-30residue repeats (Kajava and Kobe 2002). The LRR domains of the genes represented in the sample set (Online Resource Fig. 1) were found to have some variability in the conserved motif, and were very different in the following variable segment described in Fig. 6.

The motifs tended to be clustered towards both terminals of the domain, with sequences varying in both length and residue

Table 2 Percentage identities of amino acid sequences among and between the NBS domains of Actinidia chinensis NBS-LRR groups 1 and 2, and a reference sequence of Arabidopsis.At3g070401.1 representing group 1

\begin{tabular}{|c|c|c|c|c|c|c|c|c|c|}
\hline & 2555881 & 2606650 & 297874 & At3g070401.1 & 2534089 & 1719297 & 1808712 & 2300096 & 1724550 \\
\hline $2555881 \mathrm{Gp} 1$ & & 43.8 & 42.2 & 21.7 & 20.4 & 23.2 & 25.7 & 21.3 & 18.1 \\
\hline $2606650 \mathrm{Gp} 1$ & 43.8 & & 33.9 & 20.7 & 16.8 & 20.5 & 21.4 & 19.0 & 16.3 \\
\hline 297874 Gp 1 & 42.2 & 33.9 & & 22.1 & 20.3 & 24.5 & 21.3 & 21.0 & 19.2 \\
\hline At3g070401.1 & 21.7 & 20.7 & 22.1 & & 30.3 & 35.0 & 38.4 & 31.4 & 24.1 \\
\hline 2534089 Gp 2 & 20.4 & 16.8 & 20.3 & 30.3 & & 41.1 & 36.9 & 33.2 & 22.0 \\
\hline 1719297 Gp 2 & 23.2 & 20.5 & 24.5 & 35.0 & 41.1 & & 40.5 & 31.6 & 25.3 \\
\hline 1808712 Gp 2 & 25.7 & 21.4 & 21.3 & 38.4 & 36.9 & 40.5 & & 31.4 & 26.0 \\
\hline 2300096 Gp 2 & 21.3 & 19.0 & 21.0 & 31.4 & 33.2 & 31.6 & 31.4 & & 26.5 \\
\hline 1724550 Gp 2 & 18.1 & 16.3 & 19.2 & 24.1 & 22.0 & 25.3 & 26.0 & 26.5 & \\
\hline
\end{tabular}




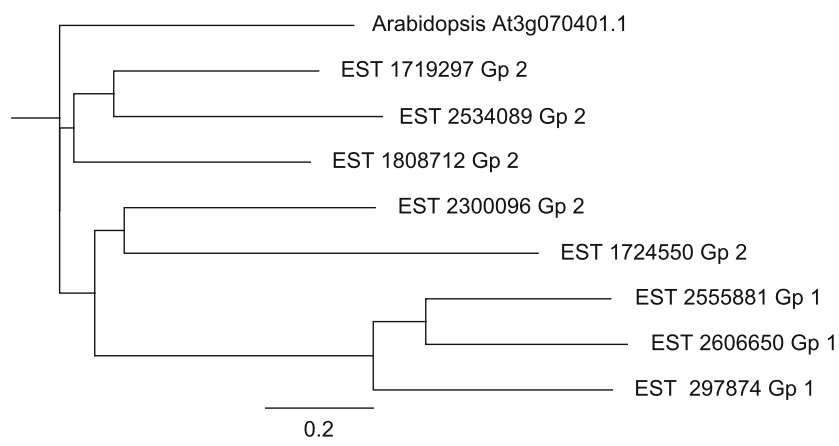

Fig. 4 Distance tree of the NBS domain of the sample set of Actinidia resistance genes constructed using Neighbor-Joining in Geneious with Arabidopsis At3g070401.1 sequence as an outgroup. The members of group 1 formed a clade while those of group 2 formed two separate clades, one of which was more closely associated with the group 1 clade than with the other group 2 clade

identity occupying the central portion. $3^{\prime}$ terminal islands of variable sequence and length were also present between the LRR motifs.

The most highly conserved motifs varied in number from three to ten in the set examined. The positions LxxLxL were occupied by aliphatic amino acids L, I or V, while the N/C position showed differing levels of conservation of the residue among the set. In EST 2300096, C was present in all but one of the ten motifs where it was replaced by A; whereas in EST 1724550, while $\mathrm{C}$ was the predominant residue, $\mathrm{N}$ and $\mathrm{T}$ also occurred in the eight motifs examined. EST 1808712 had a different residue at position nine in all five motifs. In the Actinidia genes the fifth conserved site could vary from residue 11 and was generally seen in positions 11 or 12 . The position could be constant as in EST 2300096, or vary between the positions as in EST 1724550. In all LRR domains, the pattern LxxLxL was seen to occur without the ninth and following positions being present.

Sequence conservation within the deduced amino acid sequences of MPK6 homologues

Mitogen-activated protein kinase (MAPK) signalling plays a critical role in plant disease resistance by initiating intracellular immunity pathways (Zhang and Klessig 2001). A sample set of homologues was identified in the A. chinensis EST database when compared with Arabidopsis At2g43790.1 (encoding MPK6). There was a significant degree of conservation both within the $A$. chinensis sample set and between that set and Arabidopsis. In the protein sequence of 340 amino acid residues that included the MAPK conserved site (IPR003527), the protein kinase catalytic domain (IPR000719), the serine/threonine-protein kinase active site (IPR008271) and the protein kinase ATP binding site (IPR017441), differences were recorded among all six of the A. chinensis sequences (Table 3 ) indicating that each EST represented an individual gene.

In the sequence data presented in Fig. 7, the protein kinase catalytic domain was identified between residues 19 and 306, with the A. chinensis and Arabidopsis sequences being the same length. At the N-terminal extremity of the catalytic domain, the ATP binding site, corresponding to the pattern [LIV]-G- $\{$ P $\}-[$ F Y W M G TNH $]-[$ S GA $]-\{$ PW $\}-$ [L I V C A T ] - $\{\mathrm{PD}\}-\mathrm{x}-[\mathrm{GS}$ T A C L I V M F Y ] - x $(5-$ 18)-[LIVMFYWCSTAR]-[AIVP]-[LIVMFAGCKR]-K, was found between residues 27 and 51. Two highly conserved glycine $(\mathrm{G})$ residues were present, as was the highly conserved final lysine $(\mathrm{K})$. The two conserved glycines were found in the vicinity of isoleucine, a requirement in the binding motif as leucine has been implicated in ATP binding. Residue changes were found in the site. Two of the six A. chinensis sequences shared two changes, differing from the other four, while the Arabidopsis sequence varied at four residues. All changes were in the undefined (5-18) section of the site.

Following the ATP binding site, between residues 56 and 159, was the MAPK conserved signature F-x(10)-R-E-x(72, 86)-R-D-X-K-x(9)-[CS]. This site contained the serine/ threonine protein kinase active site, pattern [LIVMFYC]x-[HY]-x-D-[LIVMFY]-K-x(2)-N-[LIVMFYCT](3), between residues 143 and 155 . Together, these two sites contained fewer residue changes than other sections of the catalytic site in comparison to Arabidopsis MPK6, with the incidence of residue changes increased toward the $\mathrm{C}$ terminal.

As all members of the sample carried within the catalytic domain accurate conserved recognition sites for activity of this class of gene product, they are likely to be active in resistance pathways in the plant.

Of the seven MPK6 homologues clustered on linkage group 22 (Fig. 1), all were seen to have amino acid differences to each other and to Arabidopsis (Table 4). Five of the gene

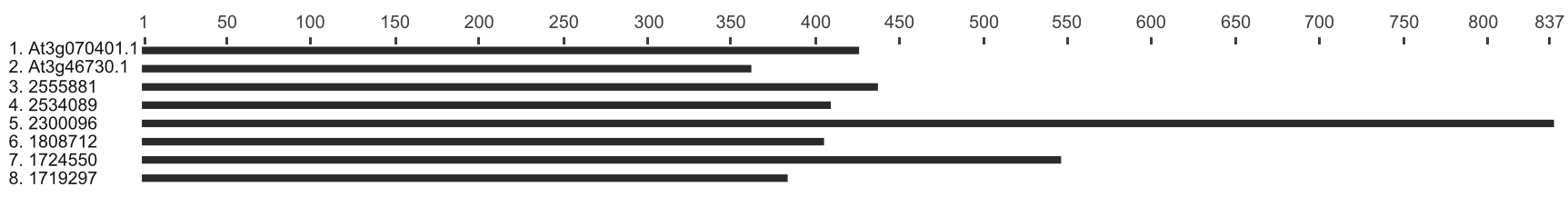

Fig. 5 The length of the LRR domain was variable in the sample set and in the Arabidopsis reference sequences. From the reference point of the MHDV conserved site, the final conserved site in the NBS domain $5^{\prime}$ to the LRR domain, sequence length ranged from 381 amino acid residues (EST 1719294) to 837 amino acid residues (EST 2300096) 
Fig. 6 The LRR motifs identified in the LRR domain of the Actinidia NBS-LRR gene sample set. In the recognised LRR motif LxxLxLxx[N/C]xL, aliphatic amino acids occupied positions 1 , 4 , and 6 in the conserved motif. The $[\mathrm{N} / \mathrm{C}]$ residue was frequently substituted by serine $(\mathrm{S})$, threonine $(\mathrm{T})$, or alanine $(\mathrm{A})$
$480-503$

$376-399$

$284-306$

$134-156$

$111-133$

$088-110$

$064-086$

$040-062$

$329-351$

$281-303$

$256-278$

$105-127$

$069-092$

$692-714$

$668-690$

$616-638$

$569-591$

$512-534$

$484-506$

$397-419$

$373-395$

$155-177$

$131-153$

$252-274$

$143-165$

$118-140$

$343-365$

$295-317$

$271-293$

$111-133$

$348-370$

$325-347$

$111-133$

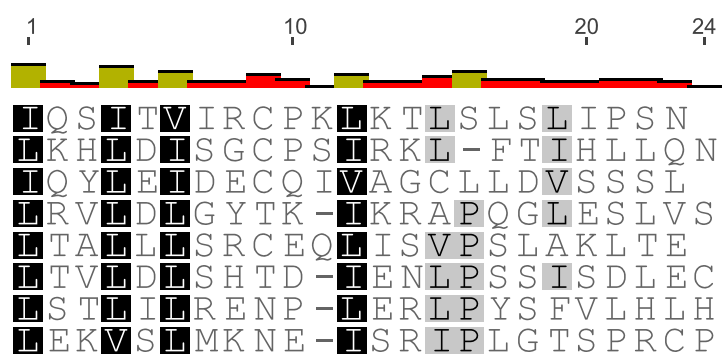

EST 1724550

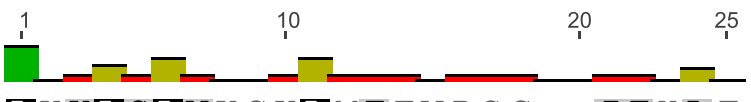

LKKLSLVKC KLMEEVP S G - - I EH L T

IA S IEILHA Y V G E L C FKA G F

LVRVCLWYS K LR DVDP - LR S L D L

LR H L S LR T NLK T I P K I G N Q N

LS KVALL G N G LR L L T - L L D L E G T L

EST 1808712

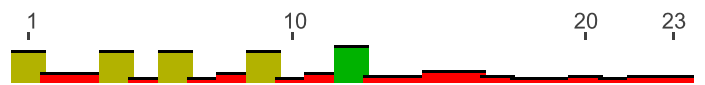

LRELFITRCKKLDAP PQS A Y NK N LNKLA IEKCD NLES LP E G W P T P IKKLSIGGCEKLEAVLA E G M T I N LRTIFIYGCNSLQS L P E L M L K N LRR LVIEKCPQIIS L F E E MEGQ LOELTIVGCQ NLT I LWQ N D V R I Q LK TLEIWECL Q LVV E W F P S P R MP LS KLSIGRCP KL GK F P S N L P L L LRHLDITGA D S L E MP S K MG K L T LOTLILK DC F LEKLPR D M N I

EST 2300096

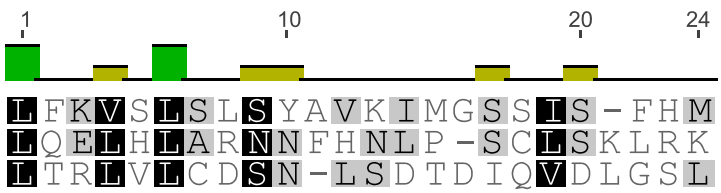

EST 2555881

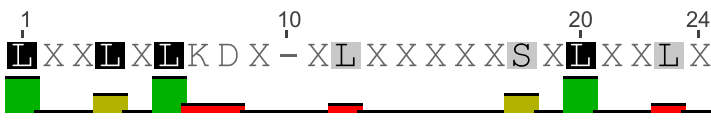

LQR IIL H C ES L EV L P - S GLWDV S LEVIKIKD N - A FK G GRWKA LD G G F LKKLTLAD T - L L D W E Y MS T G M P LR Y VA I Y G S F I I P A S ISELCNL

EST 2534089

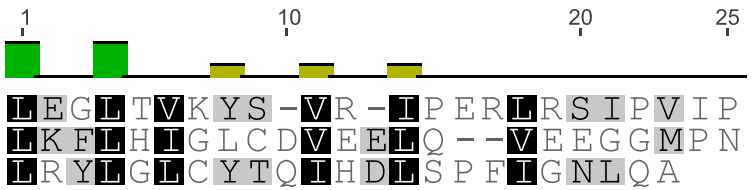

\section{EST 1719297}

markers were based on $A$. chinensis cDNA sequences and two were from $A$. deliciosa libraries (Fig. 8). The distance tree demonstrates that all ESTs represented individual genes, and that the two ESTs sourced from $A$. deliciosa libraries were more closely linked to some of the A. chinensis-derived ESTs than to each other.
FSL2 (FLAGELLIN-SENSING 2): A MAMP resistance gene against pathogen attack

Pathogens may be recognised by the plant through the perception of conserved microbial structures, the MAMPs/PAMPs. One such MAMP that is known to stimulate MAP kinase 
Table 3 Numbers of amino acid residues that differ among six Actinidia chinensis EST homologues of MPK6 encoded by At2g43790.1

\begin{tabular}{|c|c|c|c|c|c|c|c|}
\hline & EST 2409064 & EST 2270198 & EST 2121440 & EST 1996474 & EST 1879820 & EST 1738651 & At2g43790.1 \\
\hline EST 2409064 & & 2 & 4 & 3 & 3 & 2 & 27 \\
\hline EST 2270198 & 2 & & 6 & 3 & 1 & 2 & 29 \\
\hline EST 2121440 & 4 & 6 & & 3 & 5 & 4 & 26 \\
\hline EST 1996474 & 3 & 3 & 3 & & 4 & 5 & 27 \\
\hline EST 1879820 & 3 & 1 & 5 & 4 & & 3 & 30 \\
\hline EST 1738651 & 2 & 2 & 4 & 5 & 3 & & 27 \\
\hline At2g43790.1 & 27 & 29 & 26 & 27 & 30 & 27 & \\
\hline
\end{tabular}

signalling is the pattern recognition receptor-like kinase FLS2. The Actinidia homologue of the Arabidopsis FLS2 gene, EST 1696089, was included in the sample set of Actinidia resistance genes for mapping. The EST, represented by Ke990, mapped to linkage group 24. Several of the resistance genes in the sample mapped to this linkage group, in particular, genes identified through Blast searches as WIN1, NDR1 and leucine-rich repeat family proteins.

Multiple open reading frames (ORFs) were found in sequence from the location of the EST (Fig. 9a). Sequence comparison and Blast searches showed that these were also FLS2 genes. Exon 1 of proteins 1 and 2 was 3,258 bases in length while exon 1 of protein 3 was 3,261 bases in length. Exon 2 of protein 1 was 414 bases while exon 2 of proteins 2 and 3 was 450 bases in length. The introns in all three proteins were 729 bases long. The separation between proteins 1 and 2 was only 130 bases.

Deduced amino acid sequence alignment of the three genes showed that a single residue at the start of exon 1 in protein 3 was the only difference in exon 1 (Fig. 9b). Exon 2 showed more sequence diversity, and the differences varied between any two of the proteins. The variable region commenced at the same point in the proteins. The $5^{\prime}$ region of exon 2 was identical over 112 residues with the variable region confined to the 3 ' terminal. The serine/threonine protein kinase active-site signature [IVHCDLKPSNILF] occurred in exon 1 (Fig. 9c). A comparison with four other Actinidia FLS2 homologues showed between one and four residue changes at the $5^{\prime}$ terminal of exon 1, and deletions of 31 and 55 residues, together with some sequence variation, $3^{\prime}$ of the protein kinase activesite signature in the four (data not shown). The two ORFs seen in the sequence between proteins 2 and 3 did not have any sequence homology with the FLS2 sequences.

\section{Discussion}

This study reports on the identification, mapping and characterisation of a sample set of putative resistance genes in Actinidia species (kiwifruit) through homologies to Arabidopsis resistance genes. Because kiwifruit is a comparatively 'new' fruit crop, with all the parental material in breeding programmes being very few generations away from wild populations, little is known about putative resistance genes. So the results of this study provide valuable information in determining where they reside on the chromosomes, the level of diversity in gene families, or their potential for activity against Psa.

According to molecular studies Actinidia has a complex history of hybridity and polyploidization (Chat et al. 2004). In some species, and races within those species, ploidy levels from diploid to octoploid can be observed. While the mapping population in this study was functionally diploid, it has long been suggested that diploid Actinidia species are paleopolyploids (Goldblatt 1980; McNeilage and Considine 1989; Yan et al. 1997). This view is supported by cytological evidence of the base chromosome numbers of the three extant genera of the Actinidiaceae, Saurauia $(x=13)$, Clematoclethra $(x=12)$ and Actinidia $(x=29)$, that indicated that Actinidia was likely to be a paleotetraploid, with chromosome doubling followed by diploidization (He et al. 2005). Shi et al. (2010) examined the occurrence of ancient genome duplications during the evolution of Actinidia and related Ericales by calculating synonymous divergences $\left(\mathrm{K}_{\mathrm{s}}\right)$ for duplications within gene families. This study provided evidence for a well established, whole-genome doubling that occurred prior to the divergence of the taxa examined, a doubling shared by Actinidia and Camellia that took place about 75.9 million years ago, and a third doubling, specific to Actinidia, that Shi et al. (2010) dated to 28.3 million years ago. In addition to ancient whole-genome duplication events, recent smallscale doubling events may also have taken place by various processes (Blanc and Wolfe 2004; Wendel 2000). All such doubling events would provide an increase in genes available to evolve resistance to disease, and therefore, surplus genes were available for altered specificity to pathogen attack.

Plants have evolved an active defence system with two approaches. The first, the basal defence system, uses transmembrane receptors to detect MAMPs. The system is activated by these elicitors, generic signals that alert the plant to the presence of a pathogen. MAMPs, e.g., flagellins, are evolutionarily stable, core components, of the microorganism that 
EST 2409064

EST 2270198

EST 2121440

EST 1996474

EST 1879820

EST 1738651

Arabidopsis

EST 2409064

EST 2270198

EST 2121440

EST 1996474

EST 1879820

EST 1738651

Arabidopsis

EST 2409064

EST 2270198

EST 2121440

EST 1996474

EST 1879820

EST 1738651

Arabidopsis

EST 2409064

EST 2270198

EST 2121440

EST 1996474

EST 1879820

EST 1738651

Arabidopsis

EST 2409064

EST 2270198

EST 2121440

EST 1996474

EST 1879820

EST 1738651

Arabidopsis

EST 2409064

EST 2270198

EST 2121440

EST 1996474

EST 1879820

EST 1738651

Arabidopsis

$\begin{array}{ccccccc}1 & 10 & 20 & 30 & 40 & 50 & 60 \\ \mid & \mid & \mid & \mid & \mid & \mid\end{array}$

GGRFIQYNIFGNIEEVTAKYKPPIMPIGKGAYGIVCSALNSETTEHAAIKKIANAFDNKI GGRFIQYNIFGNIFEVTAKYKPPIMPIGKGAYGIVCSALNSETTEHAAIKKIANAFDNKI GGRFIQYNIFGNI FEVTAKYKPP IMPIGKGAYGIVCSALNSETSEHVAIKKIANAFDNKI GGRFIQYNIFGNI EEVTAKYKPP IMPIGKGAYGIVCSALNSETSEHVAIKKIANAFDNKI GGRFIQYNIFGN I FEVTAKYKPP IMP I GKGAYGIVCSALNSETTEHAA IKKIANAFDNKI GGRFIQYNIFGNIFEVTAKYKPPIMPIGKGAYGIVCSALNSETTEHAAIKKIANAFDNKI GGRFIQYNIFGNIFEVTAKYKPPIMPIGKGAYGIVCSAMNSETNESVAIKKIANAFDNKI ATP binding site (IPR017441)

DAKRTLREIKLLRHMDHENVVA IRDI I P P PQRES FNDVY IAYELMDTDLHQI IRSNQALS DAKRTLRE I KLLRHMDHENVVA IRD I I P P QRES FNDVY I AYELMDT DLHQ I IRSNQALS DAKRTLREIKLLRHMDHENVVA IRDI I P P PQRES FNDVYIAYELMDTDLHQI IRSNQSLS DAKRTLREIKLLRHMDHENVVA IRDI I P P PQRES FNDVY IAYELMDTDLHQ I IRSNQALS DAKRTLREIKLLRHMDHENVVA IRDI I P P PQRE S FNDVY IAYELMDTDLHQI IRSNQSLS DAKRTLREIKLLRHMDHENVVA IRDI I P P PQRES FNDVY IAYELMDTDLHQI IRSNQALS DAKRTLREIKLLRHMDHEN IVA IRD I I P P L RNAFNDVY IAYELMDTDLHQ I IRSNQALS

EEHCQYFLYQILRGLKYIHSANVLHRDLKPSNLLLNANCDLKICDFGLARVTSETDFMTE EEHCQYFLYQILRGLKYIHSANVLHRDLKPSNLLLNANCDLKICDFGLARVTSETDFMTE EEHCQYFLYQILRGLKYIHSANVLHRDLKPSNLLLNANCDLKICDFGLARVTSETDFMTE EEHCQYFLYQILRGLKY I HSANVLHRDLKP SNLLLNANCDLKICDFGLARVTSETDFMTE EEHCQYFLYQILRGLKYIHSANVLHRDLKPSNLLLNANCDLKICDFGLARVTSETDFMTE EEHCQYFLYQILRGLKY I HSANVLHRDLKPSNLLLNANCDLK I CDFGLARVTSETDFMTE EEHCQYFLYQILRGLKY I HSANVLHRDLKPSNLLLNANCDLK I CDFGLARVTSESDFMTE Serine/threonine kinase active site

YVVTRWYRAPELLLNSSDYTAAIDVWSVGCI FMELMDRKPLFPGRDHVHQLRLLMELIGT YVVTRWYRAPELLLNSSDYTTA I DVWSVGC I FMELMDRKPLFPGRDHVHQLRLLMELIGT YVVTRWYRAPELLLNSSDYTAA I DVWSVGCI FMELMDRKPLFPGRDHVHQLRLLMELIGT YVVTRWYRAPELLLNSSDYTAA I DVWSVGC I FME LMDRKPLFPGRDHVHQLRLLMELIGT YVVTRWYRAPELLLNSSDYTTA I DVWSVGC I FMELMDRKPLFPGRDHVHQLRLLMELIGT YVVTRWYRAPELLLNSSDYTTAIDVWSVGCIFMELMDRKPLF PGRDHVHQLRLLMELIGT YVVTRWYRAPELLLNSSDYTAA I DVWSVGCIFMELMDRKPLFPGRDHVHQLRLLMELIGT

PSEAELEFLSENAKKYIRQLP PYRRQSFTEKFPQVHPAAIDLVEKMLTFDPRRRLTVEDA PSEAELEFLSENAKKYIRQLPLYRRQSFTEKFPQVHPAAIDLVEKMLTFDPRRRLTVEDA PSEAELEFLNENAKKYIRQLP PYRRQSFTEKFPQVHPAA I DLVEKMLTFDPRRRLTVEDA PSEAELEFLSENAKKYIRQLPLYRRQSFTEKFPQVHPAA I DLVEKMLTFDPRRRLTVEDA PSEAELEFLSENAKKYIRQLPLYRRQSFTEKFPQVHPAAIDLVEKMLTFDPRRRLTVEDA PSEAELEFLNENAKKY IRQLP PYRRQSFTEKFPQVHPAAIDLVEKMLTFDPRRRLTVEDA PSEEELEFLNENAKRYIRQLPPYPRQS ITDKFPTVHPLAIDLIEKMLTFDPRRRITVLDA

LAHPYLTSLHDISDEPICMTPFSFDFEQHALTEEQMKELI

LAHPYLTSLHDISDEP ICMTPFSFDFEQHALTEEQMKELI

LAHPYLTSLHDISDEPICMTPFSFDFEQHALTEEQMKELI

LAHPYLTSLHDISDEPICMTPFSFDFEQHALTEEQMKELI

LAHPYLTSLHDISDEP ICMTPFSFDFEQHALTEEQMKELI

LAHPYLTSLHDISDEP ICMTPFSFDFEQHALTEEQMKELI

LAHPYLNSLHDISDEPECTIP FNFDFENHALSEEQMKELI
Fig. 7 A. chinensis MPK6 homologues together with Arabidopsis (At2g43790.1). This deduced 340 amino acid section contains the conserved sites necessary for the production of a functional protein. Amino acid differences indicated that the six A. chinensis ESTs were derived from individual genes. Sequence variability increased between the A. chinensis sample set and the Arabidopsis homologue toward the C- terminal within the catalytic domain. The catalytic domain is indicated between the grey bars, the ATP binding site and serine/threonine protein kinase site are blocked in yellow, while the conserved residues of the MAPK site are marked in blue. Residue changes between individuals are indicated in green cannot be surrendered, or significantly altered, without disabling the pathogen. However, some pathogen species have been identified where some variability in the conserved/ recognised flagellin domain has been detected, both within 
Table 4 Numbers of amino acid residues that differ among five Actinidia chinensis EST homologues of MPK6, two Actinidia deliciosa homologues, and At2g43790.1

\begin{tabular}{|c|c|c|c|c|c|c|c|c|c|}
\hline & Ke1068(4) & Ke1067 & $\mathrm{Ke} 975$ & $\operatorname{Ke} 963(1)$ & $\operatorname{Ke} 962(1)$ & Ke952 & Ke951 & $\mathrm{Ke} 972$ & Arab. \\
\hline LG22 Ke1068(4) A. deliciosa & & 2 & 2 & 0 & 2 & 0 & 3 & 0 & 7 \\
\hline LG22 Ke1067 A. chinensis & 2 & & 5 & 2 & 2 & 5 & 3 & 2 & 27 \\
\hline LG22 Ke975 A. deliciosa & 2 & 5 & & 5 & 5 & 6 & 6 & 2 & 13 \\
\hline LG22 Ke963(1) A. chinensis & 0 & 2 & 5 & & 2 & 1 & 0 & 0 & 21 \\
\hline LG22 Ke962(1) A. chinensis & 2 & 2 & 5 & 2 & & 3 & 3 & 2 & 27 \\
\hline LG22 Ke952 A. chinensis & 0 & 5 & 6 & 1 & 3 & & 4 & 0 & 27 \\
\hline LG22 Ke951 A. chinensis & 3 & 3 & 6 & 0 & 3 & 4 & & 3 & 30 \\
\hline LG1 Ke972 A. chinensis & 0 & 2 & 2 & 0 & 2 & 0 & 3 & & 8 \\
\hline Arabidopsis MPK6 & 7 & 27 & 13 & 21 & 27 & 27 & 30 & 8 & \\
\hline
\end{tabular}

Seven of the gene markers mapped to LG 22 and one marker in the sample, Ke972, mapped to LG 1 . Six of the seven markers mapping to LG 22 were clustered over a distance of $6 \mathrm{cM}$, and every marker mapped to a different position indicating that each was an individual gene. The seventh marker mapped $13.1 \mathrm{cM}$ from the cluster

species and within pathovar, permitting the pathogen to avoid detection by the host (Felix et al. 1999; Andersen-Nissen et al. 2005; Sun et al. 2006). The effectiveness of the basal defence system in restricting pathogen incursions is limited because it is predicated on the static nature of the components.

During mapping procedures of a putative FSL2 resistance gene, a MAMP receptor of flagellin, we found that three highly similar genes were present within a short region of linkage group 24. A single amino acid change at the $5^{\prime}$ terminal in protein 3 (Ke990) marked exon 1 and exon 2 carried a variable region at the extreme $3^{\prime}$ terminal in all three sequences. The comparison with other ESTs representing FLS2 genes showed

Arabidopsis AtMPK6

LG22 Ke1068(4) A. deliciosa

LG1 Ke972 A. chinensis

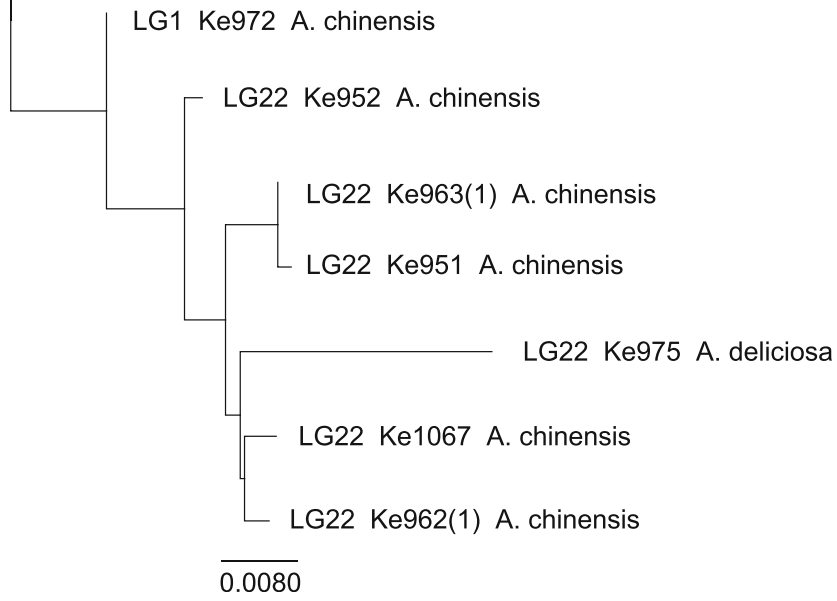

Fig. 8 Distance tree of the amino acids of the Actinidia EST homologues of MPK6 that mapped to linkage group 22 and linkage group 1 constructed a distance tree using Neighbor-Joining in Geneious with the Arabidopsis MPK6 sequence as an outgroup that, while markedly conserved and with MAMP receptors known to be relatively stable and heritable (Bent and Mackey 2007), such a high percentage identity was not general among the sample. This level of homology among the three clustered protein sequences suggests that these genes had a common origin, and are the result of a comparatively recent, and fairly localised, duplication event. The fragment of a putative LRR sequence seen between proteins 2 and 3 could possibly have been the result of an incomplete doubling.

The second aspect of the defence system is activated when microbes that are adapted to host plants express a suite of effector proteins directly into the plant cell. Many gramnegative plant pathogenic bacteria, of which Pseudomonas syringae is an example, depend on effector proteins encoded by $A v r$ genes, such as the Hop genes, entering the cytosol by the bacterial type III secretion system (Büttner and He 2009). The plant resistance gene products recognise the effector proteins of the bacterial Avr genes directly (Jia et al. 2000; Dodds et al. 2006) or indirectly (Mackey et al. 2002; Shao et al. 2003; Rooney et al. 2005). The guard and decoy hypotheses propose that the effectors on entering the plant cell cause 'perturbation' of the resistance system, separate from the resistance gene products (Bent and Mackey 2007). The virulence target may be an accessory protein (guard model), or a structural mimic of such a target (decoy model) and this perturbation acts as a signal for the activation of the resistance genes (Ade et al. 2007; Marone et al. 2013).

Of the five classes of resistance genes recognised, studies of the largest family of resistance genes, the NBS-LRR family, have shown that the NBS domain is active in signalling and contains highly conserved and strictly ordered motifs, while the LRR domain has the structural character for proteinprotein interactions. LRRs are highly adaptable domains from which very different binding specificities can evolve. Studies have shown that these domains can be under diversifying 
a

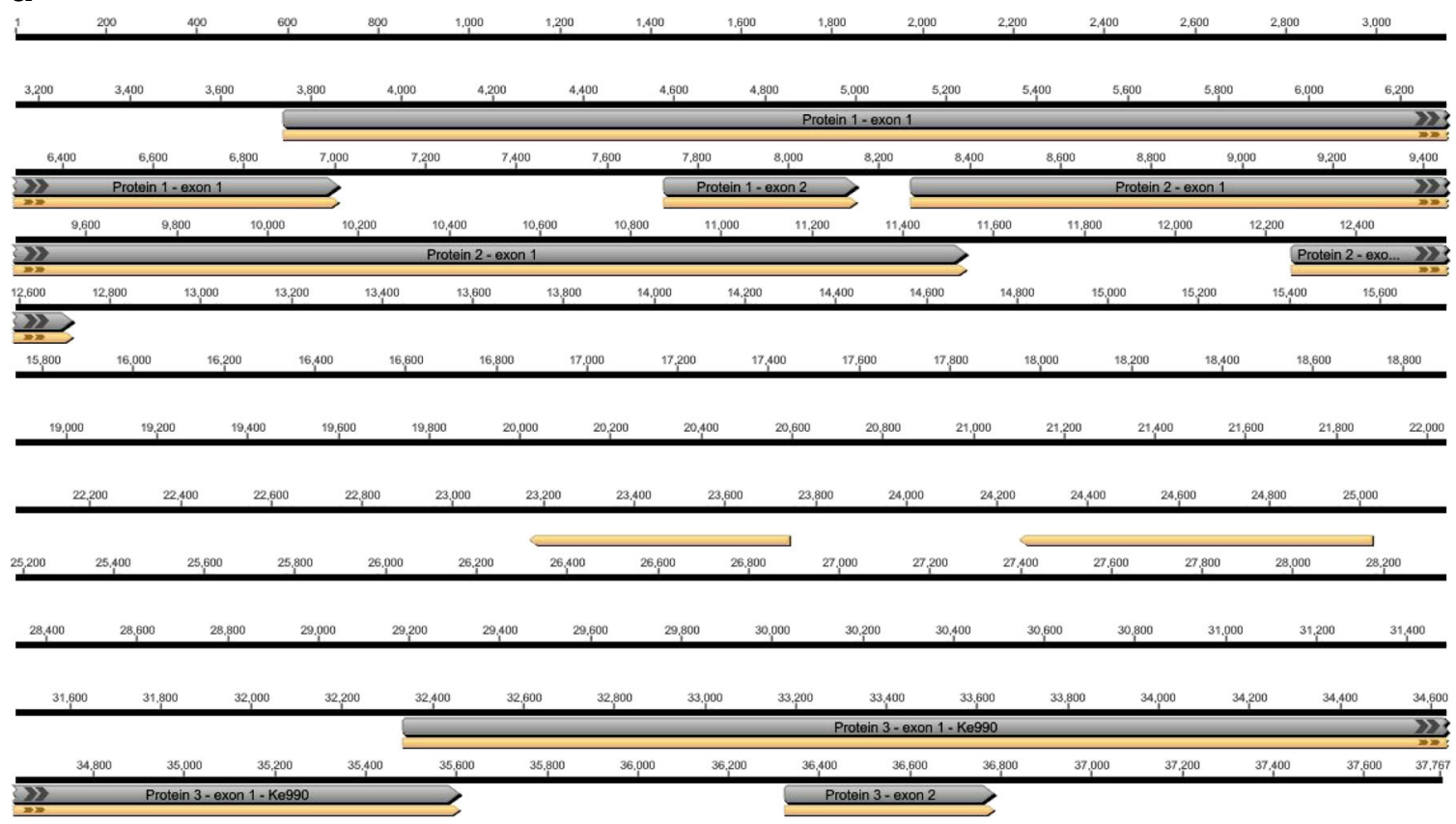

b

FLS2-Protein 2

FLS2-Protein 1
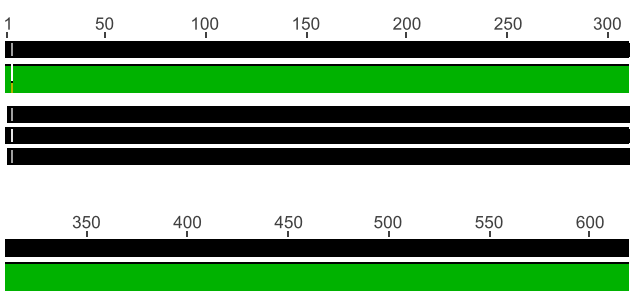

FLS2-Protein 2

FLS2-Protein 3-Ke990

\section{-}

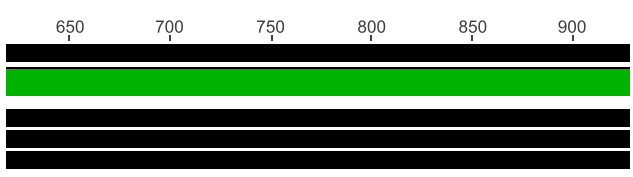

1. FLS2-Protein 2 2 . FLS2-Protein 3-Ke990

3. FLS2-Protein 1

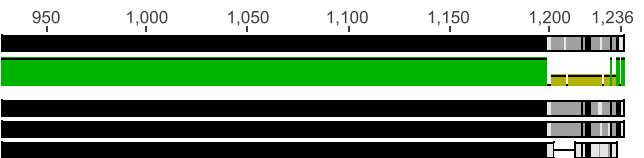

1. FLS2-Protein 2
2. FLS2-Protein $3-K e 990$
3. FLS2-Protein 1

1,000

1,010

1,020

$1,0,30$

1,040

1,060

FLS2-Protein 3-Ke990 FLS2-Protein 2

FP IVHCDLKPSN ILFDGK WEAHVS DFGTSR ILGVHLODGSS FSSSSAFOGT IG YMAPGN IKOS LLY IFMVH

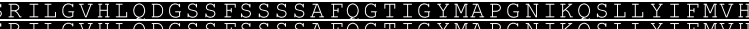
protein kinase active site

\begin{tabular}{lllllll}
$1,0,070$ & 1,080 & 1,090 & $1,1,100$ & 1,110 & 1,120 & $1,1,100$ \\
\hline
\end{tabular}

FLS2-Protein 3-Ke990

C LCACDY I L I WR IMOLFEC L LMR TV T T NVDV FS YG I IVMELL TKKRP TA L TEEDG LS LS L POLVDRA L T NG

FLS2-Protein 1

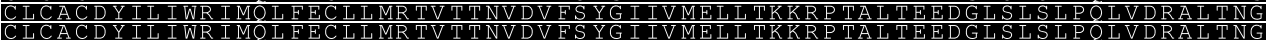

FLS2-Protein 3-Ke990 FLS2-Protein 2

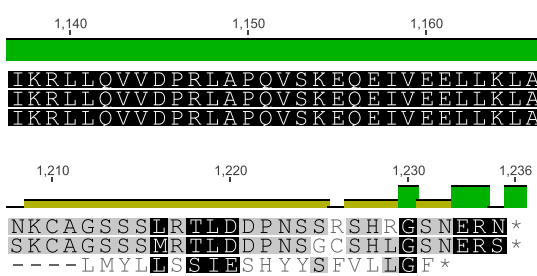

FLS2-Protein 3-Ke990

FLS2-Protein 2

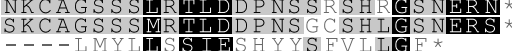

Springer 
4 Fig. 9 The cluster of FLS2 genes found on linkage group 24 where one of the genes was represented by marker Ke990. The three genes were homologous over much of their length with only the 3 ' terminal of exon 2 showing sequence variation. a The positions of three $F L S 2$ genes relative to each other on a fragment of sequence of linkage group 24. Between protein 2 - exon 2 and protein 3 - exon 1 an open reading frame was identified as possibly a fragment of an LRR gene. $\mathbf{b}$ The alignment of three FLS2 resistance genes showing the level of homology. c Sequence of the three FLS2 genes showing the protein kinase active site and the sequence variation at the $3^{\prime}$ terminal of exon 2

selection (Ellis et al. 1999; Jones and Dangl 2006), particularly at the level of predicted solvent-exposed residues along the concave face of the LRR where they not only lack conservation, but are significantly more diverse than expected from random drift (Bent and Mackey 2007). Selection pressure would advance the development of new host-pathogen specificities to recognise changing pathogen Avr proteins.

The NBS domain of the Actinidia sample displayed the highly conserved motifs related to function in most instances, but we also noted the presence of truncated ESTs. While some shortened transcripts are likely to be artefacts of library construction, the ESTs truncated through a premature stop codon, or indeed full-length transcripts as compared to Arabidopsis, could be pseudogenes and, while transcribed, evidenced by the presence of ESTs, may not produce functional proteins or be active in the resistance pathways of the plant. In two of the ESTs of the NBS-LRR sample set a premature stop codon terminated the transcript, one after the motifs of the kinase sites (EST 297874) and the other before the LRR domain (EST 2606650). It has been suggested that an NBS domain lacking an LRR domain is free to attach an alternative LRR domain, and so alter pathotypic specificity. Richly et al. (2002) proposed that recombination between diverse NSBLRR-encoding genes could drive the evolution of resistance specificities; however, Meyers et al. (2003) report that their data indicated that such wide recombination events rarely occurred, if at all. There is also evidence that the resistance cascades are tightly regulated (Marone et al. 2013). The LRR domains in the Actinidia resistance proteins were extremely variable in both length and sequence. The conserved LRR motifs were also variable in number, and carried residue differences and positional changes, mainly in the $\mathrm{C}$ terminal of the motif. All the putative proteins demonstrated numerous differences from each other so that all were the products of individual genes, and therefore, potentially with individual specificities against pathotype attack.

While the NBS domain percentage identities would suggest that members of the sample set were separate genes before the evolutionary split from Arabidopsis, caution must be taken in such evaluations as some genes may have been subjected to strong selective pressure for new variants (Charlesworth 2010), and therefore, show greater diversity in their amino acid sequence.
We recognised both TIR and CC sub-groups in the Actinidia NBS-LRR genes evaluated. Evolution of resistance-gene homologues has been studied, and Cannon et al. (2002) suggested that evolutionary histories are different for the two groups. They developed the theory that the TIR-type NBS domain is more closely related to the NBS domains in early land plants and the CC-type NBS is a later, derived innovation that arose before the split of Lycophytes (Yue et al. 2012).

Clustering of disease resistance genes has been studied and reported in many plants and molecular characterisation of such clusters has shown that some consist of both active and inactive variants of a single gene type, while others contain genes of different categories (Meyers et al. 1998; Michelmore and Meyers 1998).

A cluster of MPK6 markers that mapped to linkage group 22 was made up of genetic markers sourced from both diploid A. chinensis and hexaploid A. deliciosa. The taxonomic distance of these two groups has been questioned. At one time, both were included in $A$. chinensis, then were recognised as separate species (Liang and Ferguson 1984) with the situation now undetermined. It is apparent that $A$. chinensis has contributed to the genetic make-up of $A$. deliciosa, but whether A. deliciosa is auto- or allo-polyploid is unresolved, with some genetic evidence supporting both positions. Phylogenetic analysis of the MPK6 homologues would suggest that the markers sourced from $A$. deliciosa were individually more closely related to the $A$. chinensis markers than to each other.

Plant breeding for improvement of disease resistance can use two general categories of resistance: complete or qualitative resistance, usually controlled by a single resistance gene, and incomplete or quantitative resistance utilising multiple genes, each with a partial effect (Marone et al. 2013). Complete resistance through a single resistance gene is easy to manipulate but is often limited to a specific pathogen, and less durable as pathogens evolve. Quantitative resistance involving many genes has broader specificity and durability. To breed for highest plant health against a range of pathogens, resistance genes from both categories may be introduced into the plant by 'gene pyramiding' or 'stacking'. In this process, molecular markers can greatly assist by identifying genes and alleles that are most likely to produce phenotypes with the required specificities for pathogen recognition.

In this study, our primary purpose was to map putative resistance genes of varying activity and specificity against pathogen attack, and to identify chromosomal sites most likely to be useful in breeding genotypes. We have identified linkage groups where a disproportionate number of resistance genes reside. Further Actinidia sequencing and the published draft genome sequence of $A$. chinensis (Huang et al. 2013) will be useful to identify additional resistance genes and confirm our results.

A distinctive and reliable disease-resistance phenotype is required to relate genes to phenotype. Various disease 
symptoms must be evaluated for their weighting in evaluating resistance, or tolerance, to pathogen challenge. As EST libraries represent expression at the time of library construction, that is prior to exposure of Actinidia in New Zealand to the virulent strain of Psa, none of the markers can be regarded as specific to the pathogen. However, many were characterised as having potential to be active against Psa. When a confirmed phenotype for Psa resistance becomes available and segregating populations are identified, the genetic map will be ready for studies of resistance gene markers. This will allow characterisation of breeding germplasm to ensure inclusion of loci likely to improve resistance/tolerance to Psa, and/or to a range of bacterial pathogens.

Acknowledgments We wish to thank Drs Ross Ferguson, Gary Hill and Zac Hanley for constructive comment during the preparation of this paper. We also thank Minna Pesonen of the Design and Photography Department, Plant and Food Research, for formatting the figures and tables. This work was supported by funding from the New Zealand Ministry of Science and Innovation contract C11X1007.

Conflict of interest We do not have any conflict of interest to report.

Data archiving statement The EST sequence data are available in GenBank Data Libraries under accessions nos. FG527909-FG403522. The deposition of these EST data was described in Crowhurst et al. (2008).

Author contribution statement LGF designed markers to putative resistance genes, prepared all PCR samples for electrophoresis, analysed the results and prepared the data for map construction, and wrote the manuscript. PMD carried out the map construction. GKT processed the PCR samples through capillary array electrophoresis. KIM prepared the DNA samples. EHR catalogued kiwifruit ESTs of putative resistance genes against Arabidopsis homologues and advised on resistance gene qualities. MAM assisted with manuscript preparation and evaluation of the relevant literature. All authors participated in the tissue collection.

Open Access This article is distributed under the terms of the Creative Commons Attribution License which permits any use, distribution, and reproduction in any medium, provided the original author(s) and the source are credited.

\section{References}

Ade J, de Young BJ, Golstein C, Innes RW (2007) Indirect activation of a plant nucleotide binding site-leucine-rich repeat protein by a bacterial protease. Proc Natl Acad Sci 104:2531-2536

Agrawal A, Lively CM (2002) Infection genetics: gene-for-gene versus matching-alleles models and all points in between. Evol Ecol Res 4: $70-90$

Andersen-Nissen E, Smith KD, Strobe KL, Barrett SL, Cookson BT, Logan SM, Aderem A (2005) Evasion of toll-like receptor 5 by flagellated bacteria. Proc Natl Acad Sci 102:9247-9252

Baker B, Zambriski P, Staskawicz B, Dinesh-Kumar SP (1997) Signaling in plant-microbe interactions. Science 276:726-733

Belkhadir Y, Subramaniam R, Dangl JL (2004) Plant disease resistance protein signaling: NBS-LRR proteins and their partners. Curr Opin Plant Biol 7:391-399
Bent AF, Mackey D (2007) Elicitors, effectors, and R genes: the new paradigm and a lifetime supply of questions. Annu Rev Phytopathol 45:399-436

Bent AF, Kunkel BN, Dahlbeck D, Brown KL, Schmidt R, Giraudat J, Leung J, Staskawicz BJ (1994) RPS2 of Arabidopsis thaliana: a leucine-rich repeat class of plant disease resistance genes. Science 265(5180):1856-1860

Blanc G, Wolfe KH (2004) Functional divergence of duplicated genes formed by polyploidy during Arabidopsis evolution. Plant Cell 16: 1679-1691

Büttner D, He SY (2009) Type III protein secretion in plant pathogenic bacteria. Plant Physiol 150:1656-1664

Cannon SB, Zhu H, Baumgarten AM, Spangler R, May G, Cook DR, Young ND (2002) Diversity, distribution, and ancient taxonomic relationships within the TIR and Non-TIR NBS-LRR resistance gene subfamilies. J Mol Evol 54:548-562

Century KS, Shapiro AD, Repetti PP, Dahlbeck D, Holub E, Staskawicz BJ (1997) NDR1, a pathogen-induced component required for Arabidopsis disease resistance. Science 278:1963-1965

Charlesworth D (2010) Don't forget the ancestral polymorphisms. Heredity 105:509-510

Chat J, Jauregui B, Petit RJ, Nadot S (2004) Reticulate evolution in kiwifruit (Actinidia, Actinidiaceae) identified by comparing their maternal and paternal phylogenies. Am J Bot 91:736-747

Crowhurst RN, Gleave AP, MacRae EA, Ampomah-Dwamena C, Atkinson RG, Beuning LL, Bulley SM, Chagné D, Marsh KB, Matich AJ, Montefiori M, Newcomb RD, Schaffer RJ, Usadel B, Allan AC, Boldingh HL, Bowen JH, Davy MW, Eckloff R, Ferguson AR, Fraser LG, Gera E, Hellens RP, Janssen BJ, Klages K, Lo KR, MacDiarmid RM, Nain B, McNeilage MA, Rassam M, Richardson AC, Rikkerink EHA, Ross GS, Schröder R, Snowden KC, Souleyre EJF, Templeton MD, Walton EF, Wang D, Wang MY, Wang YY, Wood M, Wu R, Yauk Y-K, Laing WA (2008) Analysis of expressed sequence tags from Actinidia: applications of a cross species EST database for gene discovery in the areas of flavour, health, color and ripening. BMC Genomics 9:351-376

Dangl JL, Ritter C, Gibbon MJ, Mur LAJ, Wood JR, Goss S, Mansfield J, Taylor JD, Vivian A (1992) Functional homologs of the Arabidopsis RPM1 disease resistance gene in bean and pea. Plant Cell 4:13591369

Dodds PN, Lawrence GJ, Catanzariti AM, Trazel T, Wang CI, Ayliffe MA, Kobe B, Ellis JD (2006) Direct protein interaction underlies gene-for-gene specificity and coevolution of the flax resistance genes and flax rust avirulence genes. Proc Natl Acad Sci 103: $8888-8893$

Dong X, Mindrinos M, Davies KR, Ausubel M (1991) Induction of Arabidopsis defence genes by virulent and avirulent Pseudomonas syringae strains and by a cloned avirulence gene. Plant Cell 3:61-72

Ellis JG, Lawrence GJ, Finnigan EJ, Anderson PA (1995) Contrasting complexity of two rust resistance loci in flax. PNAS 92(10):41854188

Ellis JG, Lawrence GJ, Luck JE, Dodds PN (1999) Identification of regions in alleles of the flax rust resistance gene $\mathrm{L}$ that determine differences in the gene-for-gene specificity. Plant Cell 11:495-506

Felix G, Duran JD, Volko S, Boller T (1999) Plants have a sensitive perception system for the most conserved domain of bacterial flagellin. Plant J 18:265-276

Ferrante P, Scortichini M (2010) Molecular and phenotypic features of Pseudomonas syringae pv. actinidiae isolated during recent epidemics of bacterial canker on yellow kiwifruit (Actinidia chinensis) in central Italy. Plant Pathol 59:954-962

Flor HH (1956) The complementary genetic systems in flax and flax rust. Adv Genet 8:29-54

Frank SA (1996a) Statistical properties of polymorphism in host-parasite genetics. Evol Ecol 10:307-317 
Frank SA (1996b) Problems inferring the specificity of plant-pathogen genetics. Evol Ecol 10:323-325

Fraser LG, Tsang GK, Datson PM, De Silva HN, Harvey CF, Gill GP, Crowhurst RN, McNeilage MA (2009) A gene-rich linkage map in the dioecious species Actinidia chinensis (kiwifruit) reveals putative $\mathrm{X} / \mathrm{Y}$ sex-determining chromosomes. BMC Genomics 10:102

Gill GP, Harvey CF, Gardner RC, Fraser LG (1998) Development of sexlinked PCR markers for gender identification in Actinidia. Theor Appl Genet 97:439-445

Goldblatt P (1980) Polyploidy in angiosperms: monocotyledons. Plenum, New York

Gómez-Gómez L, Boller T (2000) FLS2: An LRR receptor-like kinase involved in the perception of the bacterial elicitor flagellin in Arabidopsis. Mol Cell 5:1003-1011

He ZC, Li JQ, Cai Q, Wang Q (2005) The cytology of Actinidia, Saurauia and Clematoclethra (Actinidiaceae). Bot J Linn Soc 147:369-374

Huang S, Ding J, Deng D, Tang W, Sun H, Liu D, Zhang L, Niu X, Zhang X, Meng M, Yu J, Liu J, Han Y, Shi W, Zhang D, Cao S, Wei Z, Cui Y, Xia Y, Zeng H, Bao K, Lin L, Min Y, Zhang H, Miao M, Tang X, Zhu Y, Sui Y, Li G, Sun H, Yeu J, Sun J, Liu F, Zhou L, Lei L, Zheng X, Liu M, Huang L, Song J, Xu C, Li J, Ye K, Zhong S, Lu B-R, He G, Xiao F, Wang H-L, Zheng H, Fei Z, Liu Y (2013) Draft genome of the kiwifruit Actinidia chinensis. Nat Commun 4:2640. doi:10. 1038/ncomms3640, www.nature.com/naturecommunications

Jia Y, McAdams SA, Bryan GT, Hersley HP, Valent B (2000) Direct interaction of resistance gene and avirulence gene products confers rice blast resistance. EMBO J 19:4004-4014

Jones JD, Dangl JL (2006) The plant immune system. Nature 444:323329

Kajava AV, Kobe B (2002) Assessment of the ability to model proteins with leucine-rich repeats in light of the latest structural information. Protein Sci 11:1082-1090

Kedzierske L, Montgomery J, Curtis J, Handman E (2004) Leucine-rich repeats in host-pathogen interactions. Arch Immunol Ther Exp 52: 104-112

Kuang H, Woo S-S, Meyers BC, Nevo E, Michelmore RW (2004) Multiple genetic processes result in heterogeneous rates of evolution within the major cluster disease resistance genes in lettuce. Plant Cell 16:2870-2894

Liang CF, Ferguson AR (1984) Emendation of the Latin name Actinidia chinensis Pl. var. Hispida C.F. Liang. Guihaia 4:181

Mackey D, Holt BF, Wiig A, Dangl JL (2002) RIN4 interacts with Pseudomonas syringse type III effector molecules and is required for RPM1-mediated resistance in Arabidopsis. Cell 108:743-754

Marone D, Russo MA, Laidò G, De Leonardis AM, Mastrangelo AM (2013) Plant nucleotide binding site-leucine-rich repeat (NBS-LRR) genes: active guardians in host defence reponses. Int J Mol Sci 14: $7302-7326$

Martin GB, Brommonschenkel JC, Frary A, Ganal MW, Spivey R, Wu T, Earle ED, Tanksley SD (1993) Map-based cloning of a protein kinase gene conferring disease resistance in tomato. Science 262: $1432-1436$

McNeilage MA, Considine JA (1989) Chromosome-studies in some Actinidia taxa and implications for breeding. N Z J Bot 27:71-81

Meyers BC, Chin DB, Shen KA, Sivaramakrishnan S, Lavelle DO, Zhang Z, Michelmore RW (1998) The major resistance gene cluster in lettuce is highly duplicated and spans several megabases. Plant Cell 10:1817-1832

Meyers BC, Dickerman AW, Michelmore RW, Sivaramakrishnan S, Sobral BW, Young ND (1999) Plant disease resistance genes encode members of an ancient and diverse protein family within the nucleotide-binding superfamily. Plant J 20:317-332

Meyers BC, Kozik A, Griego A, Kuang H, Michelmore RW (2003) Genome-wide analysis of NBS-LRR-encoding genes in Arabidopsis. Plant Cell 15:809-834
Michelmore RW, Meyers BC (1998) Clusters of resistance genes in plants evolve by divergent selection and a birth-and-death process. Genome Res 8:1113-1130

Mindrinos M, Katagiri F, Yu G-L, Ausubel FM (1994) The A. thaliana disease resistance gene RPS2 encodes a protein containing a nucleotide-binding site and leucine-rich repeats. Cell 78(6):1089-1099

Morel J-B, Dangl JL (1997) The hypersensitive response and the induction of cell death in plants. Cell Death Differ 4:671-683

Nomura K, Mecey C, Lee Y-N, Imboden LA, Chang JH, He SY (2011) Effector-triggered immunity blocks pathogen degradation of an immunity-associated vesicle traffic regulator in Arabidopsis. PNAS 108:10774-10779

Pan Q, Wendel J, Fluhr R (2000) Divergent evolution of plant NBS-LRR resistance gene homologues in dicot and cereal genomes. J Mol Evol 50:203-213

Parker MA (1996) The nature of plant-parasite specificity. Evol Ecol 10: 319-322

Richly E, Kurth J, Leister D (2002) Mode of amplification and reorganization of resistance genes during recent Arabidopsis thaliana evolution. Mol Biol Evol 19:76-84

Rooney HC, Van't Klooser JW, van der Hoorn RA, Joosten MH, Jones JD, de Wit PJ (2005) Cladosporium Avr2 inhibits tomato Rcr3 protease required for $\mathrm{Cf}-2$-dependent disease resistance. Science 308: 1783-1786

Shao F, Golstein C, Ade J, Stoutemyer M, Dixon JE, Innes RW (2003) Cleavage of Arabidopsis PBS1 by a bacterial type III effector. Science 301:1230-1233

Shi T, Huang H, Barker MS (2010) Ancient genome duplications during the evolution of kiwifruit (Actinidia), and related Ericales. Ann Bot 106:497-504

Shi H, Shen Q, Qi Y, Yan H, Nei H, Chen Y, Zhao T, Katagiri F, Tang D (2013) BR-signaling kinase 1 physically associates with flagellin sensing 2 and regulates plant innate immunity in Arabidopsis. Plant Cell Prev. doi:10.1105/tpc.112.107904

Spoel SH, Dong X (2012) How do plants achieve immunity? Defence without specialized immune cells. Nat Rev Immunol 12:89-100

Sun W, Dunning FM, Pfund C, Weingarten R, Bent AF (2006) Withinspecies polymorphism among Xanthomonas campestris pv. campestris flagellins alters elicitation of Arabidopsis FLS2-dependent defences. Plant Cell 18:764-779

Tameling WIL, Elzinga SDJ, Darmin PS, Vossen JH, Takken FLW, Haring MA, Cornelissen BCJ (2002) The tomato R gene products 1-2 and Mi-2 are functional ATP binding proteins with ATPase activity. Plant Cell 14:2929-2939

Tan S, Wu S (2012) Genome wide analysis of nucleotide-binding site disease resistance genes in Brachypodium distachyon. Comp Funct Genomics. doi:10.1155/2012/418208

Torii KU (2004) Leucine-rich repeat receptor kinases in plants: structure, function, and signal transduction pathways. Int Rev Cytol 234:1-46

Wendel JF (2000) Genome evolution in polyploids. Plant Mol Biol 42: 225-249

Whalen MC, Innes RW, Bent AF, Staskawicz BJ (1991) Identification of Pseudomonas syringae pathogens of Arabidopsis and a bacterial locus determining avirulence on both Arabidopsis and soybean. Plant Cell 3:49-59

Whitham S, Dinesh-Kumar SP, Choi D, Hehi R, Corr C, Baker B (1994) The product of the tobacco moasic virus resistance gene N: similarity to toll and interleukin-1 receptor. Cell 78(6):1101-1115

Yan G, Yao J, Ferguson AR, McNeilage MA, Seal AG, Murray BG (1997) New reports of chromosome numbers in Actinidia (Actinidiaceae). N Z J Bot 35:181-186

Yue J-X, Meyers BC, Chen J-Q, Tian D, Yang S (2012) Tracing the origin and evolutionary history of plant nucleotide-binding site-leucinerich repeat (NBS-LRR) genes. New Phytol 193:1049-1063

Zhang S, Klessig DF (2001) MAPK cascades in plant defense signalling. Trends Plant Sci 6:520-527 